\title{
シンポジューム網内系の機能 \\ I. The Effect of a New RES Stimulant on Neoplasia
}

\author{
John H. Heller, Emile G. Bliznakov, \\ John P. Ransom, David J. Wilkins \\ and Varsenig Z. Pasternak
}

To give an introductory statement on the regulation of RE activities is a challenge which cannot adequately be met since, by definition, all the activities are not known.

To increase the difficulty there remain many who argue which cellular elements should be included within the definition of the RES. Obviously, until this is established, an attempt at delineation of the functions of the system as a whole, or its components in particular, is impossible.

However, even if we take those cellular elements whose place within the RES is agreed to by all, we have the impression of a whole battery of functions, many apparently unrelated, strongly suggesting that we have far too little knowledge of this remarkable system of cells to delineate with any precision the spectrum of all its actions.

Undoubtedly this is a system with many activities. Broad understanding of the activities of the RES has been hampered to a degree by lack of an interdisciplinary approach to the total problem. Thus the immunologist will not concern himself with metabolic activities. Hematologists look at the system in still another specialized way. Lack of understanding of the RES has been fostered by the fact that too many specialists have been looking at segments of the system in a specialized way and too few generalists have looked at the system in a total way. In no category in the field of medicine is it more important to bring an interdisciplinary approach than in the area of the RES.

At this symposium we celebrate the half-century mark of the discovery of the RE cell. One of the earliest characteristics noted was its ability to phagocytose. Phagocytosis can be described and has been-innumerable times - in the course of the last half century. However, during that period of time, while physical chemistry moved ahead and presented us with many techniques, insights and fundamental quantitative approaches, the biomedical field continued to talk about phagocytosis descriptively. Even the apparent quantification of phagocytosis of certain heterogeneous colloids such as carbon is still essentially descriptive. Until we have a fundamental insight into the physical chemistry of the particle and of the cell, we can, and indeed we must, ask ourselves how a cell can identify a particle.

Presumably there are only three parameters which are distinguishable - size, electrical surface charge or zeta potential, and the surface groups. This dictates that we must begin to study such phenomena by designing particles so as to control these parameters.

This means working with colloids of definitive particle diameter and tailoring the surface of such monodisperses in order to control the zeta potential and surface groups. We shall include a short commentary on this aspect of our RES research in a paper whose primary subject is RES stimulation for we feel that such techniques are important to measure function. 
With the use of emulsion polymerization, one can create batches of colloids of definitive particle diameter in material such as polystyrene. These monodisperses are extremely precise and extraordinarily symmetrical. In order to label them with a tag which is an integral part of the structure of the colloid it was necessary to synthesize cetyl iodide ${ }^{125}$ and incorporate this in the emulsion polymerization process. Subsequent to obtaining a tagged colloid of definitive particle size, it was necessary to tailor the surface. The first problem tackled was that of changing the charge. We felt that this could best be done by the technique of coacervation, whereby two macromolecules of opposite charge, under appropriate conditions, will form an extremely thin capsule, probably of the order of a monolayer around the particle in question. Two suitable molecules for this were gelatin and gum arabic.

As can be seen from Figure 1, by selecting different $\mathrm{pH}$, one can have either a positive or a negative charge. However, from this figure, it is apparent at blood $\mathrm{pH}$ only negative charges were possible. This necessitated making gelatin more positive. This, in turn, necessitated undertaking a biochemical program to introduce many lysine groups into the gelatin so that we would have a polylysyl gelatin of far greater positivity.

Having accomplished this, the same figure shows it is now possible to have a highly positive or a highly negative surface charge, or any point in between, including no significant charge at all in blood $\mathrm{pH}$.

An example of the selective difference in phagocytosis of different RE elements can be seen in Figure 2 where a highly positive colloid is compared to one identical in every respect except that one is highly negative ( $40 \mathrm{mv}$ negative) and the other positive (40 mv positive). It is obvious that such techniques open the possibility of making similar coacervates around living, attenuated or killed bacteria or viruses, and literally sending them to those RE elements where an optimal effect may be obtained.

We are now using this technique in vaccines and the early results are provocative.

These data are presented to suggest that there are available, not only quantitative methods of measuring different aspects of RE activity, but that from this knowledge new analytical and therapeutic techniques may easily devolve.

Figuve 1 Microelectrophoresis of polystyrene particles coated with various macromolecules.

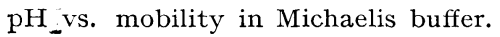

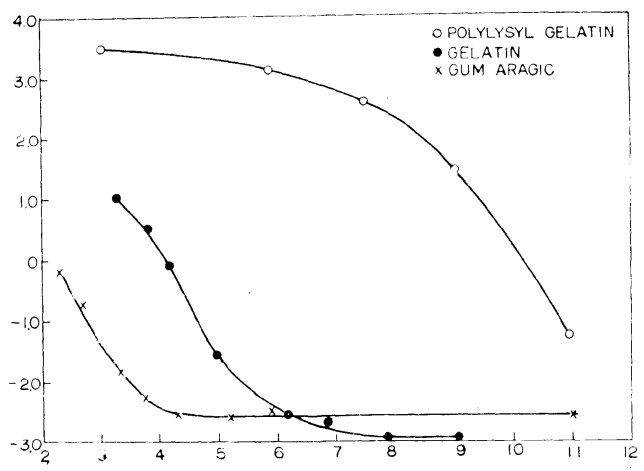

Figure 2 Per cent distribution of positive and negative particles five minutes after injection.

\begin{tabular}{l|c|c}
\multicolumn{3}{c}{ Per Cent Recovered } \\
& Positive & Negative \\
\hline Blood & 7.0 & 21.0 \\
Liver & 44.0 & 56.0 \\
Spleen & 1.5 & 8.0 \\
Lungs & 25.0 & 7.5 \\
\hline
\end{tabular}


Concommitant with the above work, we began the search for RES stimulants. There is considerable data in the literature, too voluminous to incorporate here, indicating that significant damage to the RES permits the neoplastic process to flourish. What was badly needed in order to flesh out the hypothesis of a host-tumor equilibrium was data indicating that a stimulant to the RES might inhibit the neoplastic process.

In common with many others, we looked to microbial products in order to search for a chemical species which might significantly stimulate RE function but have no toxic effects. We decided that any stimulant to be useful could not be or contain protein or polysaccharide because of the antigenic and pyrogenic effects and hence must fall in the lipid family. The fact that Corynebacterium and organisms with much lipid in the cell walls seemed to stimulate the RES gave further hope that the lipids were the right areas in which to search. We extracted lipids from a large number of pathogens, and all were toxic.

We then began to look at non-pathogens aud found in some of them, such as Saccharomyces cerevisiae, that we could extract a crude lipid mixture which was stimulatory and apparently non-toxic ${ }^{(1)}$. The yield, however, was extraordinarily small, being of the order of micrograms per kilo of lyophilized material.

As the chemical work proceeded on this crude material, it reminded us of similar lipidic material that we had previously encountered in a totally different research area in certain shark livers.

We, therefore, thought it worthwhile to explore the idea that the type of lipid we sought might be present in shark liver. It must be borne in mind that the type of lipids in shark livers vary as a function of species, sex, age and season of the year. In order to procure fresh shark liver of different species, age and sex it was necessary for us to engage in our own procurement. Of eighteen species caught, three seemed to possess an active lipid whose yield of active crude material was in grams per kilo, as opposed to milligrams.

The two species providing the largest yield are the Tiger (Galeocerdo cuvier) and the Lemon (Negoprion breviostris). The material does not seem to be present in immature livers. Many livers are dark with pigment probably derived from the blood or bile and indeed some of the livers are black. In such livers we have found no active material. It is in the large, very fatty light brown livers that we find the material we seek ${ }^{(2)}$.

It became apparent that the active lipid began to degrade within fifteen minutes after the shark's death. This necessitates bringing them in alive. Since the sharks are caught far out at sea, this demanded development of a variety of techniques of bringing them in alive, including a specially designed shark scow, sacrificing the sharks on the docks and processing the livers immediately in a dockside laboratory.

The material is treated in the following way. One kilogram of fresh shark liver is homogenized in a blender with 2 liters of absolute ethanol. This homogenate is then diluted with 1 liter of ether and $250 \mathrm{ml}$ of hexane, and then allowed to stand for two to three hours. It is then filtered. The freshest liver gives the most active lipid; but, because of its freshness, one extraction will not remove all the lipid. Therefore, the extraction procedure is repeated by taking up the wet residue in 1 liter of ethanol, 1 
liter of ether and $250 \mathrm{ml}$ of hexane. It is then filtered once more, the residue discarded, and the solvents are removed in vacuo. The concentration is then taken up in hexane and the hexane layer is filtered through anhydrous sodium sulphate. The hexane is then removed under vacuum, and the remaining lipid is dissolved in anhydrous ether. The ether solution is then treated with five volumes of cold acetone, and the mixture is kept in the freezer at $-28^{\circ} \mathrm{C}$. for 24 hours. After centrifuging at $-5^{\circ}$ to $-10^{\circ}$ the yellow acetone-rich supernatant is discarded. The residue is transferred into a flask with anhydrous ether. The ether is removed by distillation, and the lipid is stored at $-28^{\circ} \mathrm{C}$. under nitrogen. The yield is about 20 per cent by weight of wet shark liver. This lipid is still only partially purified in this form but quite active in stimulating phagocytosis by the carbon clearance technique.

The partially purified material then undergoes further fractional crystallization. The colorless, partially purified, seventeen times recrystallized more active material is put through a silicic acid column. The columns are packed with silicic acid and celite. The columns are washed with acetone and hexane and charged with the lipid. The neutral fractions are removed with hexane after which a succession of solvents of increasing polarity are used.

Numerous fractions are derived from this column, one of which is very active biologically as evidenced by a marked increase in phagocytosis as determined by several phagocytic tests. The stimulation of phagocytosis can be of the order of ten fold. This material has no proteins or polysaccharide. It has no phosphorous. Thin layer chromotography indicates that it travels as a single spot. Nuclear magnetic resonance, infra-red and ultra-violet have given us further insights into structure, but any further speculation of specific structure at this time would be premature. Analytic and synthetic activities are going forward and in the near future we hope we may have definitive information on the molecular structure.

This lipid appears to be an uncommon material, and we have not found it in significant amounts in any other reasonably available source. There is no pyrogenicity from this material, nor have we found any obvious toxicity when given in very large amounts up to $16 \mathrm{mg}$ per rat or $10 \mathrm{mg}$ per rabbit. In vitro tests with macrophages indicate that the lipid is very rapidly phogacytosed and disappears in a matter of hours. We have no idea as to its fate beyond this point. Initially we used this lipid in microbial systems, including Klebsiella pneumoniae, cholera, Salmonella typhimurium, etc. As a standard we have used Salmonella typhimurium in mice, and the following chart is typical of the result of administration of the lipid prior to vaccine. It can be seen that the administration of the lipid markedly potentiates the efficacy of the vaccine. Fig. 3

In the next table (Fig. 4) one can see the effect of the administration of the lipid given to rabbits in terms of antibody nitrogen. More surprising was the next figure (Fig. 5) where it was found that not only does the lipid increase antibody nitrogen, but in a system of passive immunization (opsonized challenge cells) it conveys increased protection.

In contrast to other substances, the lipid elicits a greater number of leukocytes than other lipids, as can be seen from the next table (Fig. 6) and at 24 hours over $90 \%$ of them are $\mathrm{RE}$ cells. Behavior in this respect is similar to that of endotoxin from Gram 
Figure 3 Effect of Shark Lipid 'Restim' on Survival Time and Survival in Mice challenged with two 1,000,000 $\mathrm{LD}_{50}$ 's of $S$. Typhimurium

\begin{tabular}{c|c|c}
\hline Treatment & $\begin{array}{c}\mathrm{SD}^{50}(95 \% \\
\text { conf. lim. }\end{array}$ & $\begin{array}{l}\% \text { Survivors } \\
(20 \text { days })\end{array}$ \\
\begin{tabular}{c|c|c} 
'Restim' 1 dose before \\
and 1 dose after
\end{tabular} & $16.5(10.9-24.9)$ & 40 \\
$\begin{array}{c}\text { vaccine } \\
\text { 'Restim' 1 dose before }\end{array}$ & $10.5(7.25-15.2)$ & 33 \\
$\begin{array}{c}\text { vaccine. } \\
\text { Restim' 1 dose after }\end{array}$ & $8.6(6.4-11.5)$ & 60 \\
vaccine & $8.0(6.0-10.6)$ & 30 \\
Vaccine only & $2.4(2.2-2.7)$ & 0 \\
'Restim' only, 2 doses & $2.2(1.9-2.5)$ & 0 \\
No treatment &
\end{tabular}

FIGURE 4 The Effect of a new RES Stimulant on Neoplasia

Effect of Measurement of Antibody Nitrogen in Response of Rabbits to Egg Albumin with the Addition of intravenous Restim-S

\begin{tabular}{c|c|c}
$\begin{array}{l}\text { Treatment SL, } \\
\mathrm{Mg} / \mathrm{rabbit}\end{array}$ & $\begin{array}{c}\mathrm{Ab} \mathrm{N} \\
\mathrm{ug} / \mathrm{ml}\end{array}$ & $\begin{array}{c}\text { \% Increase } \\
\text { (average) }\end{array}$ \\
\hline 400 & 135.1 & 733 \\
200 & 118.2 & 640 \\
100 & 99.2 & 536 \\
0 & 18.5 & - \\
\hline
\end{tabular}

Figure 5 The Fffect of Restim-S on Infections in Mice Produced by Opsonized and NonOpsonized Cells of S. Typhimurium.

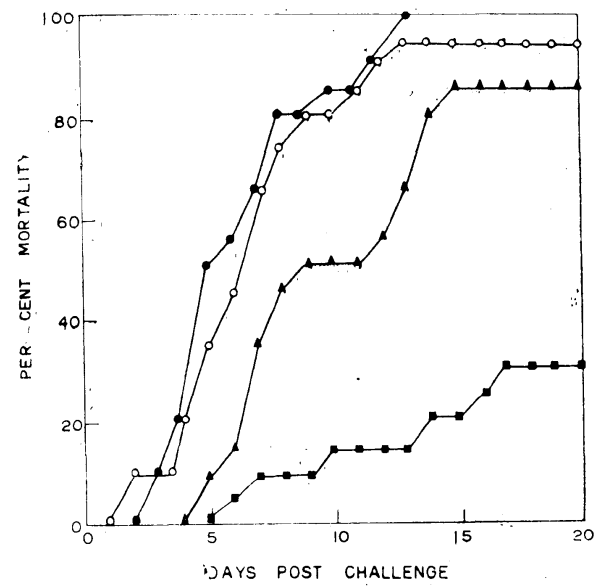

- Untreated mice challenged with non-opsonized bacteria;

Restim-S-treated mice challenged with non-opsonized bacteria;

- Untreated mice challenged with opsonized bacteria;

口 Restim-S-treated mice challenged with opsonized bacteria.

negative cells. Evidence that it does not behave as endotoxin in a classical sense can be seen in the Shwarzman reaction. Intradermal injections of the lipid in experiments which include intradermal injections of endotoxin shows a Shwarzmann reaction with the endotoxin only. There is one further interesting point about the role of the lipid in the Shwarzman reaction. This is illustrated in the next table (Fig. 7).

With these data at hand, we thought we were ready to proceed into a study of the effect of such stimulation on the neoplastic process. We began initially with the Rous sarcoma virus. The following figure (Fig. 8) shows the number of takes after a 14-day period in animals that received the lipid along with anti-serum from immunized adult chickens. We followed these animals for a protracted time and found that those with takes which had received lipid developed regressions. We then decided to continue experiments wherein no lipid was given in advance. One group was given lipid at the 7 th and 14 th day after virus injection. The following figure (Fig. 9) shows 
Figure 6 The Effect of a New RES Stimulant of Neoplasia Effect of Various Agents on Peritoneal Exudates of Mice

\begin{tabular}{|c|c|c|c|c|c|}
\hline Agent & $\begin{array}{l}\text { Dose, mg. } \\
\text { per mouse }\end{array}$ & $\begin{array}{l}\text { Bound Ly } \\
\mathrm{ug} / \mathrm{ml}\end{array}$ & $\begin{array}{l}\text { Total Ly } \\
\mathrm{ug} / \mathrm{ml}\end{array}$ & $\begin{array}{l}\text { Bound } \mathrm{Ly} \\
/ 10^{6} \text { cells }\end{array}$ & $\frac{\text { Cells } / m l}{10^{6}}$ \\
\hline Triolein & $\begin{array}{r}50 \\
25 \\
10 \\
3\end{array}$ & $\begin{array}{r}12.20 \\
9.94 \\
6.92 \\
-\end{array}$ & $\begin{array}{r}17.6 \\
12.4 \\
8.8 \\
5.8\end{array}$ & $\begin{array}{r}3.43 \\
1.60 \\
0.87 \\
-\end{array}$ & $\begin{array}{l}3.5 \\
6.2 \\
7.9 \\
6.9\end{array}$ \\
\hline $\begin{array}{l}\text { Ethyl } \\
\text { Stearate }\end{array}$ & $\begin{array}{r}100 \\
50 \\
25 \\
3\end{array}$ & $\begin{array}{r}66.60 \\
13.80 \\
18.70 \\
-\end{array}$ & $\begin{array}{r}84.0 \\
18.0 \\
23.0 \\
6.2\end{array}$ & $\begin{array}{r}16.0 \\
1.7 \\
11.8 \\
\end{array}$ & $\begin{array}{r}3.7 \\
8.1 \\
10.7 \\
7.5\end{array}$ \\
\hline Endotoxin & $\begin{array}{l}0.6 \\
0.5 \\
0.1 \\
0.05\end{array}$ & $\begin{array}{l}7.0 \\
4.9 \\
8.7 \\
7.2\end{array}$ & $\begin{array}{l}7.8 \\
5.8 \\
9.4 \\
7.2\end{array}$ & $\begin{array}{l}0.47 \\
0.42 \\
0.70 \\
0.77\end{array}$ & $\begin{array}{r}14.97 \\
11.80 \\
12.42 \\
9.40\end{array}$ \\
\hline Restim & $\begin{array}{l}3.0 \\
2.0 \\
1.0 \\
0.5\end{array}$ & $\begin{array}{l}5.0 \\
6.1 \\
4.8 \\
2.4\end{array}$ & $\begin{array}{l}6.8 \\
8.6 \\
6.8 \\
3.5\end{array}$ & $\begin{array}{l}0.44 \\
0.42 \\
0.59 \\
0.33\end{array}$ & $\begin{array}{r}11.4 \\
14.4 \\
8.2 \\
7.3\end{array}$ \\
\hline None & - & 1.1 & 2.1 & 0.47 & 2.4 \\
\hline Saline & & 1.3 & 1.8 & 0.41 & 3.3 \\
\hline
\end{tabular}

Figure 7 The Effect of a New RES Stimulant on Neoplasia

\begin{tabular}{l|c|c}
\hline & $\begin{array}{c}\text { Intradermal } \\
\text { Preparation* }\end{array}$ & $\begin{array}{c}\text { Local Shwartz- } \\
\text { man Reaction }\end{array}$ \\
\hline Lipid & LPS $50 \mu$ & 0 \\
before & LPS $25 \mu$ & 0 \\
Control & LPS $10 \mu$ & 0 \\
& Saline & 0 \\
& LPS $50 \mu$ & $/ / / /$ \\
& LPS $25 \mu$ & $/ / / /$ \\
& LPS $10 \mu$ & $/ / /$ \\
& Saline & 0
\end{tabular}

*Provoking Dose $10 \mathrm{mg}$ LPS in $1 \mathrm{ml}$ saline, I.V., 24 hrs. after intradermal preparation.
Figure 8 Rous Sarcoma Virus (ATTC) $10^{-1}$ dilution. Each curve represents 18 animals Antiserum 1 cc given subcutaneously 90 minute before challenge. Iv lipid ( $2 \mathrm{mg} / 100 \mathrm{gm}$ ) $48 \mathrm{hr}$ piror to challenge

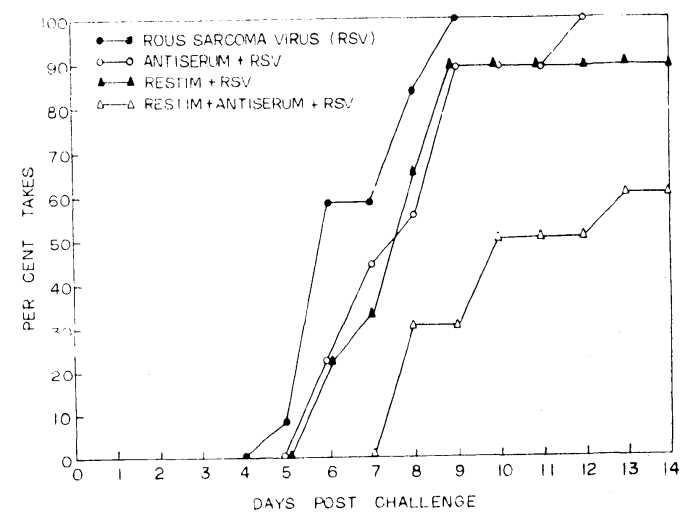

regressions in this group as compared to the controls. This sort of reaction has not been reported in the literature in the case of young chicks (17-18 days old in our experiments) 3,4. Furthermore, there was an increase in survival of lipid treated chicks which might indicate reduction of metastases (Fig. 10).

We then began with another viral type of neoplasm, that of the Friend leukemia virus. The spleen size is an indication of the severity of the process, and the animals 
Figure 9 Rous Sarcoma Virus (ATTC) $10^{-1}$ dilution. Each curve represents 18 animals. Iv. lipid (2 mg/100 $\mathrm{gm}$ ) $48 \mathrm{hrs}$ piror to challenge

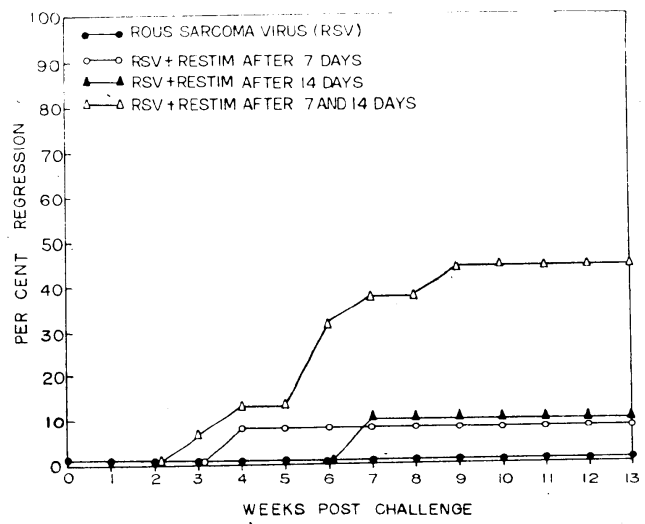

Figure 10 Rous Sarcoma Virus (ATTC) $10^{-1}$ dilution. Each curve represents 18 animals. Iv. lipid (2mg 100, $\mathrm{gm}) 48 \mathrm{hrs}$ prior to challenge

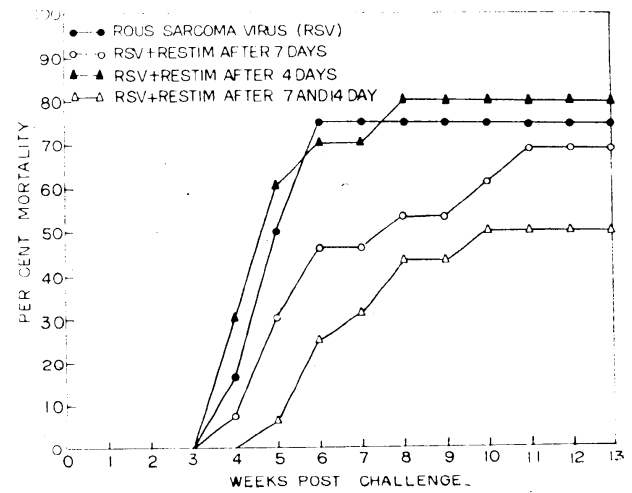

which received lipid 14 days after challenge had a significantly reduced spleen size by a factor of more than 10 fold. We then decided to do mortality studies, and the next figure (Fig. 11) shows the results of the two groups after thirteen weeks. We have just recently begun studies in presumably non-virus produced tumors. We still have relatively few animals in the subsequent groups and the data must be presumed to be preliminary; however, they are presented here because they seem to follow a general pattern similar to Rous sarcoma. A very large number of animals have been followed in this latter tumor.

We have begun studies with Ehrlich ascites. We have made a "vaccine" which involves precipitation with dihydrostreptomycin ${ }^{5}$.

The next figure (Fig. 12) shows the result of mortality in the various groups. It can be seen at the optimal dose there is zero mortality. Another factor which is evident and has been seen often enough to make us feel that this must be watched very carefully is that too great dose or too small a dose can produce a worsening of the

Figure 11 Friend Leukemia Virus. The dose as represented by the SED500 was .25 SED500 units. 20 animals in each group $.2 \mathrm{mg}$ lipid per $25 \mathrm{gr}$. mouse 48 hrs before challenge.

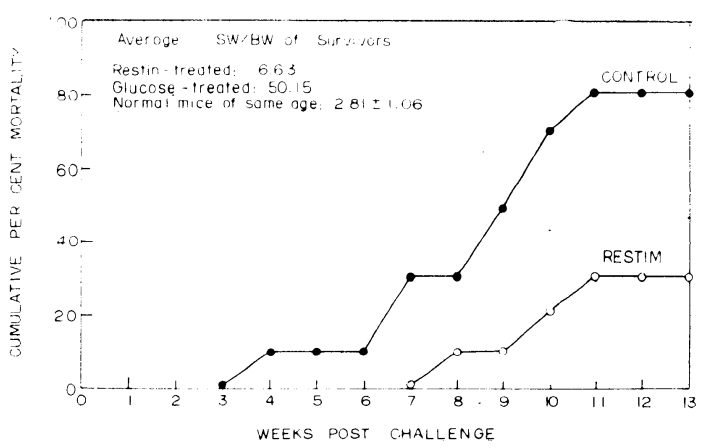


Figure 12 Ehrlich Ascites Tumor in Mice C is non-vaccinated control $\mathrm{V}$ is vaccinated control $.02, .04, .08$ indicates $\mathrm{mg}$ per $25 \mathrm{gr}$ mouse of lipid given $48 \mathrm{hrs}$ before challenge. All lipid treated mice also received vaccine. 10 animals per group. 100,000 to 200,000 Ehrlich Ascites cells was the challenge dose per mouse.

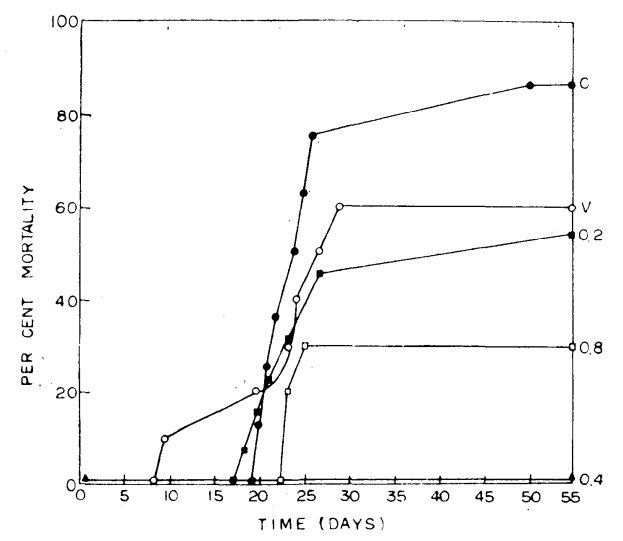

Figure 13 Sarcom 180 in mice. The abcessa is given in per cent of maximum growth reached by each tumor. Lipid dose is given in $\mathrm{mg}$ per 25 gr mouse. Lipid given intravenously 24 hrs before implantation of tumor.

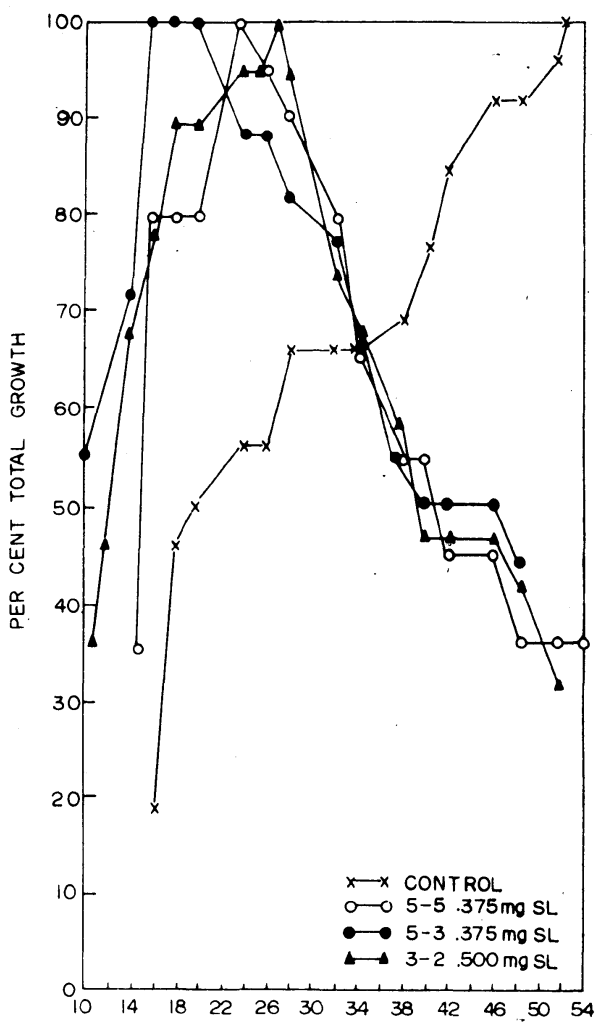

DAYS AFTER TUMOR TRANSPLANT

disease, as opposed to regression or protection.

In another non-viral produced tumor, Sarcoma 180 , it is obvious that a similar trend can be seen with some regressions occuring in the experimental groups (Fig. 13).

Finally, data in Walker carcinoma in rats gave a series of results similar to the previous studies. (Figures 14 and 15.)

It must be stated here that these results are still at an early stage. The numbers of the animals and the number of experiments are still small, but the trend seems to be distinct. We have much experimentation yet ahead with dose, numbers of doses and time of administration. We must also try to ascertain more information as to the mechanisms of action of this lipid. Further analytical and synthetic work is continuing, and once we know the specific structure, we will obviously modify it in order to see if we can find a more powerful RES stimulant, particularly in the field of neoplasia. We shall also search for an analog of this material which preliminary evidence indicates may block RE function and hence be useful in such fields as homotransplantation. 
FIGURE 14 Walker Carcinoma in rats. Tumor transplanted as a homogenate. The treated groups had five injections of $2 \mathrm{mg}$ of lipid at 3day intervals with the last given 14 days prior to challenge. 3 more injectoins of lipid were given on the $7 \mathrm{th}, 14$ th and 21 st day after challenge. 20 animals in each group.

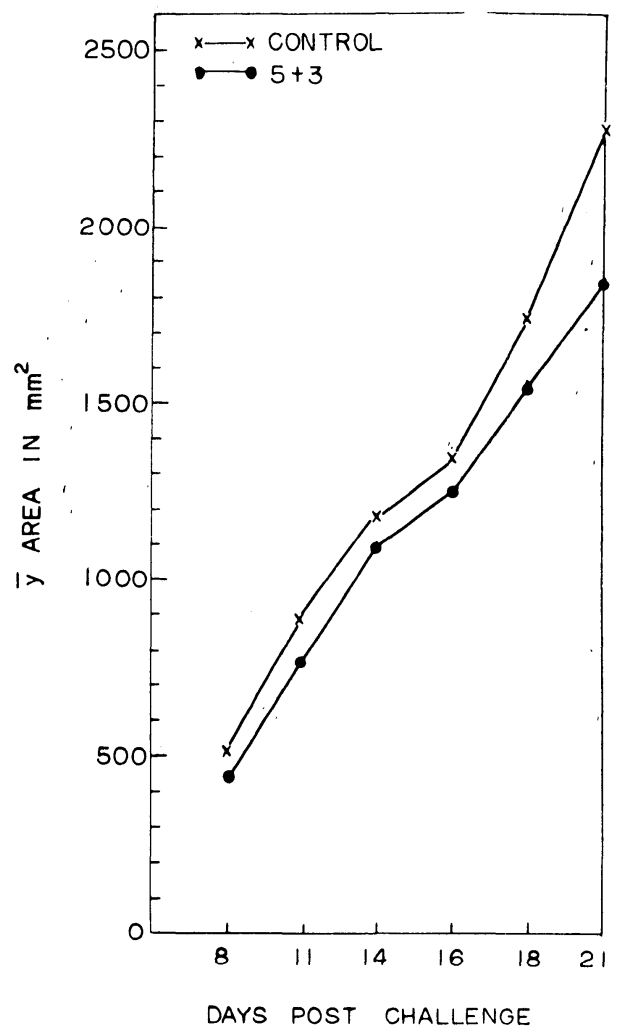

FIgURE 15 Walker Carcinoma in rats. Tumor transplanted as a homogenate. The treated groups had five injections of $2 \mathrm{mg}$ of lipid at 3 day intervals with the last given 14 days prior to challenge. 20 animals in each group. The solid circles had 3 more injections on post-challenge day 7,14 and 21. The open circles had 1 more injection on post-challenge.day 7 .

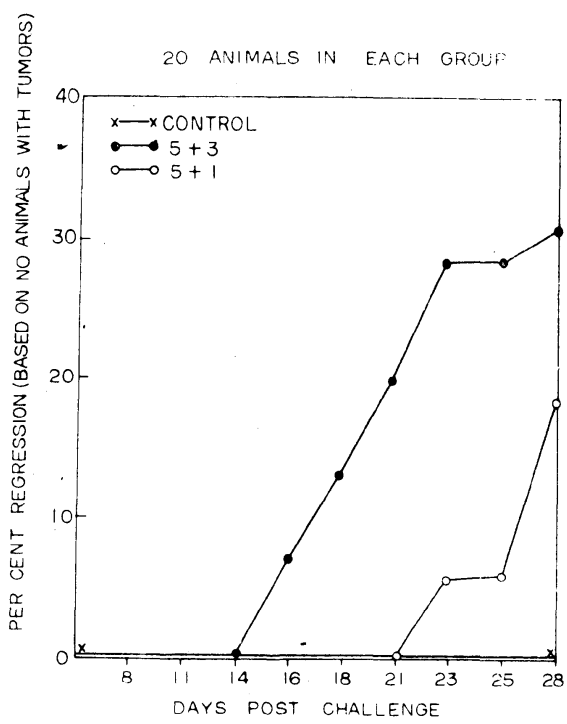

\section{References}

1. The Effect of Reticuloendothelial Stimulating Agent (Restim) on Resistance of Mice, Heller, J.H., J.P. Ransom and V.Z. Pasternak, Journal of Bacteriology, 84: 466, 1962.

2. A New RES Stimulating Agent (Restim) from Shark Livers, Heller, J.H., J.P. Ransom, V.Z. Pasternak and M.S. Heller, Nature, 199: 904, 1963.

3. The Cause of Cancer, Cassel and Co., London, 1931. Gye, W.E. and W.J. Purdy.

4. Growth and Regression of the Rous Sarcoma as a Function of the Age of the Host. Freire, P.M., E. Bryan and F. Duran-Reynals, Cancer Res., 13: 386-88, 1953.

5. Immunization against Ehrlich's Ascites Carcinoma with Streptomycin Complexes of Tumor Cells, Polglase, W.J., Nature, 197: 301, 1963. 


\section{討議}

Berry : Heller 博士の大变注目すへき論文についてこ れから御質問, 御追加を始めます.

博士が述へられましたようにこの種の各項について は殆んど疑問の余地がないかと思います．それで割当 てられた残りの時間は Heller 博士に対する質問に有
効に使えると思います。

このような次第ですが，誰方か御発言，御質問ござい ませんか.

もしございませんなら，Heller 博士，どうも御立派な 発表を有難うございました。 